Szegedi Tudományegyetem, Fogorvostudományi Kar, Parodontológiai Tanszék* Szegedi Tudományegyetem, Fogorvostudományi Kar, Konzerváló és Esztétikai Fogászati Tanszék** Szegedi Tudományegyetem, Mérnöki Kar, Élelmiszermérnöki Intézet ${ }^{\star \star *}$

\title{
Gyökéramputált és betéttel restaurált felső moláris fogak törési ellenállásának in vitro vizsgálata
}

\author{
Elözetes tanulmány
}

DR. SZABÓ BALÁZS*, DR. EÖRDEGH GABRIELLA**, DR. SZABÓ P. BALÁZS***, DR. FRÁTER MÁRK**

\begin{abstract}
Bevezetés: Jelen vizsgálat célja az ép parodonciummal és a furkáció érintett, parodontális defektussal körülvett, gyökéramputált és betéttel restaurált fogak töréssel szembeni ellenállásának vizsgálata.

Anyag és módszer: 14 darab kihúzott és gyökérkezelt, II. osztályú MOD kavitással rendelkező felső nagyőrlő fogat csonkfelépítést követően kompozit betéttel restauráltunk. Ezt követően a fogak meziobukkális gyökerét amputáltuk és a fogakat a gyökerek körüli beágyazás szintje alapján két csoportba osztottunk. Beágyazást követően a fogakat törésig statikus terhelési tesztnek tettük ki. A töréssel szembeni ellenállás mellett a törés mintázatát is vizsgáltuk.

Eredmények: Az ép parodontális viszonyokkal rendelkező csoport töréssel szembeni ellenállása átlagosan 2655,53 N $(\mathrm{n}=7, \mathrm{SD}= \pm 1107,27 \mathrm{~N})$ volt, míg a károsodott parodontális viszonyokkal rendelkezó csoporté $1624,12 \mathrm{~N}(\mathrm{n}=7, \mathrm{SD}=$ $\pm 535,03 \mathrm{~N}$ ). A törési mintázat tekintetében ez utóbbi csoport összes mintája kedvezőtlen, nem restaurálható törést hozott létre.

Megbeszélés: jelen vizsgálat alapján a gyökéramputált fogak körül lévő csontos megtámasztás mértéke befolyásolja a fogak töréssel szembeni ellenállását és a létrejött törés mintázatát is.
\end{abstract}

Kulcsszó: gyökéramputáció, furkáció, töréssel szembeni ellenállás, overlay, gyökérkezelt fogak

\section{Bevezetés}

A parodontálisan érintett felső moláris fogak kezelése a felső posterior régió anatómiai sajátosságai miatt számos nehézséget rejt magában. Ilyenek például a furkációk jelenléte és a gyökerek egymáshoz, valamint az arcüreghez való sajátos viszonya is [12,30]. Ismert tény, hogy sikertelen kezelés miatt a parodontálisan érintett fogak közül a felső molárisok kerülnek leggyakrabban eltávolításra [21]. Mivel a felső molárisok egyedi, bonyolult gyökéranatómiával rendelkeznek, ha a tapadásveszteség eléri a furkációt, az további, a kezelés sikertelenségéhez vezető problémákat okozhat [26]. Emellett egyes parodontális kórformák (pl. LAP, lokalizált agresszív parodontitisz) nagyobb valószínüséggel érintenek moláris fogakat. Hermann és mtsai. vizsgálata szerint, ha az említett fogakban a furkáció hozzáférhetővé válik, az már több mint 30\%-os tapadásveszteséget jelent [14]. Továbbá, mivel a szabaddá vált furkáció nehezen tisztítható a páciensek számára, a moláris fogak általában rosszabbul reagálnak a nem sebészeti parodontális terápiára, mint az egygyökerü fogak [18]. Ugyanakkor a fogorvostudomány jelenlegi, robbanásszerű fejlődése, valamint pácienseknek a saját foguk megtartására irányuló megnövekedett igénye miatt egyre több olyan fog kerül kezelésre és megtartásra, amelyet korábban eltávolítottak volna. Emiatt a hemiszekciók, a premolarizációk és a gyökéramputációs kezelések lényegesen gyakoribbá váltak. Az Amerikai Parodontológiai Társaság definíciója szerint a gyökéramputáció olyan sebészeti beavatkozás, amely során egy többgyökerü fog egy vagy több gyökere a furkáció szintjében sebészileg eltávolításra kerül, míg a fog koronai része és a megtartott gyökerek érintetlenek maradnak [2]. A gyökéramputáció kulcsfontosságú beavatkozást jelenthet stratégiailag fontos fogak megtartása esetén, vagy ha más kezelési lehetőségek, például az implantációs beavatkozás, akadályokba ütköznek (pl. az arcüreg közelsége miatti limitált csontmennyiség, vagy parodontálisan érintett, dohányzó páciens stb.). A kiváltó ok alapján a gyökéramputáció indikációit parodontológiai és endodonciai csoportokba sorolhatjuk. DeSanctis és Murphy csoportosítása alapján a klasszikus parodontális okok között lehet közepes mértékű vagy előrehaladott furkáció-érintettség, súlyos csontveszteség, mely egy vagy több gyökeret érint, elözőek terápiarezisztens formái, a fog egy gyökerét érintő súlyos recesszió vagy dehiszcencia, valamint a szomszédos fogak gyökereinek egymáshoz viszonyított kedvezőtlen pozíciója [11]. Az endodonciai indikációk az alábbiak lehetnek: gyökérfraktúra és perforáció, külső rezorbció, sikertelen gyökérkezelés, gyökérkáriesz 
vagy endoparodontális léziók [11]. Ez megegyezik Basaraba és mtsai. korábbi ajánlásával [5]. Mielőtt az operátor kiválasztaná, hogy melyik gyökeret kell eltávolítani, az alábbi tényezőket kell figyelembe vennie: a gyökerek körül lévő csont mennyisége, a furkáció anatómiája, a gyökér és gyökércsatorna konfigurációja az esetleges vagy korábbi endodonciai kezelés tekintetében, és az apex körüli szövetek állapota [13, 25]. Attól függően, hogy endodonciai vagy parodontológiai okból kívánjuk elvégezni a gyökéramputációt, a gyökerek körül lévő csontszövet mennyisége általában eltérő, és ez jelentősen befolyásolhatja a fogak későbbi stabilitását és prognózisát. Fontos hangsúlyozni, hogy amint a gyökéramputáció indikációja megállapítást nyert, szükséges elvégezni a megtartandó fogak gyökérkezelését és gyökértömését [5]. A gyökérkezelt fogak prognózisa nem csak a gyökérkezelés sikerességén, hanem az elkészült koronális restaurátumon is múlik. A gyökérkezelés és az azt követő gyökéramputáció után megmaradó foganyagmennyiség kiemelt jelentőséggel bír, ugyanis a gyökérkezelt fogak statikai ereje, töréssel szembeni ellenállása közvetlen összefüggést mutat a megtartott foganyag mennyiségével [28]. Ezáltal a gyökéramputáció és a kezelt fog sikerességét a koronális restauráció is jelentősen meghatározza.

Jelen vizsgálat célja, hogy összehasonlítsa az ép parodonciummal és a sérült, furkáció-érintett, parodontális defektussal körülvett, gyökéramputált és betéttel restaurált fogak töréssel szembeni ellenállását és a létrejött törés mintázatát.

\section{Vizsgálati anyag és módszer}

A vizsgálat során parodontológiai okok miatt eltávolított 14 darab felső első nagyőrlő fogat használtunk fel (etikai engedély: 43/2017-SZTE). A frissen eltávolított fogakat $5,25 \%$-os $\mathrm{NaOCl}$ oldatba helyeztük 5 percre, majd fiziológiás sóoldatban szobahőmérsékleten tároltuk. A fogakat az eltávolítást követő 6 hónapon belül felhasználtuk. A fogak előkészítése során a lágyszöveteket kézi depurátorral távolítottuk el. Kizárási kritériumnak számított a fogak válogatásakor a nagyobb méretű koronális vagy gyökéri káriesz, jól látható repedés, korábbi gyökérkezelés, csappal vagy koronával történő helyreállítás vagy rezorbció. A vizsgálat során felhasznált fogak gyökereinek közös jellemzői voltak, hogy a gyökerek nem fuzionáltak, és a gyökérhosszok standard (palatinális 12,5-14,5 mm; meziobukkális és disztobukkális 11,5-13 mm) méretűek voltak. A CEJ (zománc-cement határ) és az adott furkáció-bemenet (meziális, bukkális, disztális furkáció-bemenet és a CEJ között mért távolság; M-CEJ, B-CEJ, D-CEJ) távolságát ugyancsak standard értékek (M-CEJ: 2,5-3,5 mm; B-CEJ: 3-4 mm; D-CEJ: 3,5-4,5 mm) szerint határoztuk meg. A felhasznált fogak $80 \%$-ának koronai orovesztibuláris átmérője 8,0 és $9,0 \mathrm{~mm}$ közötti, a többi minta esetében ez az adat 9,0 és 10,0 mm között válto- zott. A fogak koronai részének meziodisztális átmérőjét is megmérve mindössze $10 \%$-os eltérést engedélyeztünk a saját átlagukhoz képest. A mintákat egy kiképzett operátor készítette elő a folyamat elejétől a végéig, minden fog esetében ugyanaz a személy.

Standardizált méretű MOD (mezio-okkluzio-disztalis) kavitásokat preparáltunk Cara és mtsai. ajánlása alapján [7]. A kavitások approximális ládáinak orovesztibuláris átmérője a fog orovesztibuláris átmérőjének 2/3-a, míg az okkluzális láda a fog orovesztibuláris átmérőjének fele volt. A mélység tekintetében az approximális ládák a CEJ felett $1 \mathrm{~mm}$-rel végződtek, míg az okkluzális láda a bukkális csücsökcsúcsokhoz képest 3,5 mm-es mélységgel rendelkezett. Az approximális ládák meziodisztális szélessége $2 \mathrm{~mm}$ volt. A kavitásalakítást követően minden fogat gyökérkezeltünk és gyökértömést készítettünk. A gyökérkezelés során crown down technikát alkalmaztunk 2-3-4 Gates Glidden fúrókkal (Union Broach, York, USA), majd a gyökércsatornát a teljes munkahoszszon Protaper file-okkal (S1, S2, F1, F2, F3) (Dentsply, Maillefer, Ballaigues, Svájc) és ISO Hedström reszelővel munkáltuk meg. A gyökércsatorna átöblítését $2 \mathrm{ml} 5 \%$-os $\mathrm{NaOCl}$ oldattal végeztük minden eszköz, file használatát követően. A gyökércsatorna kiszárítása után a gyökértömést egy-poén technikával a feltágítással megegyező nagyságú guttaperhával (F3 guttapercha, Maillefer-Dentsply, Ballaigues, Svájc) és sealer (AH plus; Dentsply De Trey GmbH, Konstanz, Németország) alkalmazásával végeztük el. A gyökértömést visszafúrtuk a bemeneti nyíláshoz képest 2-3 mmre apikálisan, majd a gyökércsatorna bemeneteket üvegionomer cementtel (EQUIA Forte, GC Europe, Leuven, Belgium) zártuk le. Az összes mintán ugyanazt az adhezív előkészítést és csonkfelépítést végeztük el. A kavitás tisztítását és szárítását követően az adhezív kezelést egy enyhe önsavazó együveges adhezívvel (G-Premio BOND, GC Europe, Leuven, Belgium) végeztük. Az adhezív fotopolimerizációja 40 másodperc volt. A csonkfelépítés rövid üvegszál megerősítésü kompozittal (short fibre-reinforced composite, SFRC, everX Posterior, GC Europe, Leuven, Belgium) történt. A felépítés során az SFRC-t ferdén rétegezve, 3-4 mm vastag rétegekben applikáltuk a kavitásba, követve a gyártó utasításait. A csonkfelépítést addig folytattuk, amíg csak 1-1,5 mm hiányzott a kavitás bármely részénél a fog külső kontúrjához képest. Rétegenként 40 másodperces fotopolimerizáció történt. Ezt követően a már korábbi MOD kavitásnak megfelelően betét (overlay) kavitást preparáltunk, követve a korábbi kavitás határait. A fog minden csücske redukálásra került $2 \mathrm{~mm}$-el a kiindulási állapothoz képest. Parodontális szondával mérve, mind az approximális, mind az okkluzális kavitás 2-2,5 mm-es helyet biztosított a készítendő overlay számára. A preparálást követően kétfázisú egyidejü lenyomatot vettünk a mintákról. A fogtechnika a lenyomat alapján labor kompozitból (GRADIA, GC Europe, Leuven, Belgium) készítette el az overlayeket. 
A beragasztásig a fogakat vízben tároltuk. A beragasztás során a kavitások felszíneit felérdesítettük, szelektív zománcsavazást végeztünk 30 másodpercig, majd a mintákat lemostuk és leszárítottuk. A betétek belvilágát felérdesítettük, majd ezt követően szilanizáltuk (CERAMIC PRIMER II, GC Europe, Leuven, Belgium). A beragasztás adhezívvel (G-Premio BOND, GC Europe, Leuven, Belgium) és egy magas töltöttségű flow kompozittal (G-aenial Universal Flo, GC Europe, Leuven, Belgium) történt. A felesleges ragasztó eltávolítását követően 40 másodperces fotopolimerizációt végeztünk minden oldalról (200 másodperc/fog). Ezután a restaurátum finírozása és polírozása történt. Az összes restaurált minta meziobukkális gyökerét amputáltuk. A gyökéramputáció a gyökéroszlás magasságában történt horizontális vágással, 14-es méretű fekete gyémánt fissura fúróval (881.31.014 FG - Brasseler USA Dental, Savannah, GA). A vágási felület mentén a gyökéroszlásnál az esetleges, nem tökéletesen eltávolított gyökérmaradványokat forgó eszközzel hozzásimítottuk a gyökértörzshöz. Ennek célja egy tisztítható, nem retentív felszín létrehozása.

A restaurált és gyökéramputált fogakat véletlenszerúen 2 csoportba osztottuk, 7-es elemszámmal mindkét csoportban. A 2 csoport csak a beágyazás - a beágyazó által szimulált csontos megtámasztás - tekintetében tért el egymástól. Az 1. csoport esetén a mintákat ép parodontális viszonyoknak megfelelóen ágyaztuk be, figyelembe véve a gyökéramputáció okozta eltéréseket. A gyökéramputáció által nem érintett területen, a CEJ-tól $2 \mathrm{~mm}$-re apikálisan kezdődött a beágyazó anyag szintje, ezzel az egészséges csontszintet szimulálva. A furkáció területén pedig az ép interradikuláris szeptumnak megfelelően elérte a furkáció boltozatát. A 2. csoport esetén a mintákat a károsodott parodontális viszonyoknak megfelelóen ágyaztuk be. A beágyazó anyag egységesen a furkáció boltozatáig ért, horizontális csontpusztulás képét utánozva. Ez 1-es furkációérintettségnek felel meg. A gyökerek felszínét szeparáló folyadékkal (Ruber-Sep, Kerr, Orange, USA) vontuk be a parodontális rostok szimulálására, majd a mintákat a csoportoknál meghatározott szintig beágyaztuk speciális beágyazó múgyantába (Technovit 4004, Heraeus-Kulzer, Wehrheim, Németország). Mindkét csoport esetén a restaurált fogakat 1-1 ép, korábban eltávolított foggal együtt ágyaztuk be, ügyelve arra, hogy szoros kontaktpont legyen a fogak között. Így a vizsgálandó, gyökéramputált fogak mindkét oldalról meg voltak támasztva. A restaurált fogakat a beágyazást követően mechanikai tesztelésnek tettük ki (Lloyd 1000R, Lloyd Instruments Ltd, Fareham, Egyesült Királyság), és törésig terheltük őket. A mechanikai tesztelést $2 \mathrm{~mm} /$ perc sebességgel végeztük, a töréssel szembeni ellenállást Newton-ban $(\mathrm{N})$ regisztráltuk [31]. A mechanikai tesztelés után megvizsgáltuk a törési mintázatot. Az elkülönítést (restaurálható és nem restaurálható törés) Scotti és mtsai. ajánlása alapján végeztük [27]. A létrejött törés utáni állapot akkor mondható restaurálhatónak, ha a törés a CEJ szintjében vagy fölötte végződik, míg a CEJ alatt végződő kedvezőtlennek és nem restaurálhatónak minősül.

\section{Eredmények}

Az ép (1. csoport) és a károsodott (2. csoport) parodontális viszonyoknak megfelelően beágyazott fogak átlagos töréssel szembeni ellenállás-értékeket és a hozzájuk tartozó standard deviációt (SD) az 1. ábra mutatja. $A z$ 1. csoport (ép parodoncium) tagjainak töréssel szembeni átlagos ellenállása 2655,53 N $(\mathrm{n}=7, \mathrm{SD}=$ $\pm 1107,27 \mathrm{~N}$ ), míg a 2. csoport tagjaié (sérült parodoncium) $1624,12 \mathrm{~N}(\mathrm{n}=7, \mathrm{SD}= \pm 535,03 \mathrm{~N})$ volt. Ez azt jelenti, hogy az 1 . csoportbeli, ép parodontális viszonyoknak megfelelően beágyazott fogak töréssel szembeni ellenállása jelen vizsgálatban nagyobbnak bizonyult, mint a 2. csoportbeli, sérült parodontális körülményeknek megfelelően beágyazott fogaké. Ez a különbség több mint 1,6-szoros. A kis elemszám miatt a mintán statisztikai próba nem alkalmazható, de a különbségben talán látható egy tendencia.

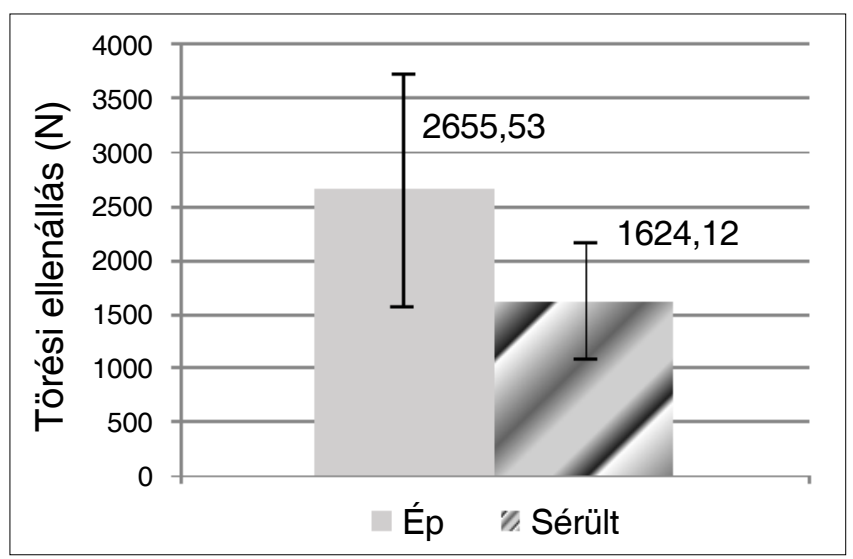

1. kép: Törési ellenállások értéke ép és sérült parodoncium esetén. A diagram jól szemlélteti az eltérő parodontális viszonyok közötti jelentős különbséget, annak ellenére,

hogy ez a kis elemszám miatt statisztikailag nem mutatható ki.

A törési mintázatok tekintetében a sérült parodontális körülményeknek megfelelően beágyazott csoportban egyetlen olyan fog sem volt, ami a Scotti féle restaurálhatósági kritériumoknak megfelelt volna, míg az ép parodontális körülményeknek megfelelően beágyazott fogak esetében megközelítőleg egyenlő arányban találtunk a törési teszt után restaurálható és nem restaurálható fogakat.

\section{Megbeszélés}

Gyökéramputációt már az 1800-as évek óta végeznek [1]. Az azóta eltelt hosszú idő alatt a gyökéramputáció folyamata rengeteget változott, sok kérdés merült fel vele kapcsolatban. llyen például a sínezés kérdése, ami fontos szempont a gyökéramputáción átesett fogak esetében. Gyökéramputációnál az érintett fog és a szomszédos fogak csiszolását és összekötését, sínezését szokták alkalmazni. A sínezés előnyös lehet a gyökéramputált fog szempontjából, ugyanis segíti a fogat érő 
erők eloszlását, megakadályozza a fog elmozdulását, vándorlását, csökkentheti az ételbeékelődést és javítja a fog stabilitását [3]. Ugyanakkor korábbi vizsgálatok alapján nem mindig szükséges a sínezés a fog restaurálásának sikeressége érdekében [3, 16]. A sínezés szükségességét a fog mobilitása alapján minden esetben individuálisan kell eldönteni. Klavan eredményei szerint, ha egy felső moláris fog egyik gyökerét sebészetileg eltávolítjuk, az nem feltétlenül növeli a fog mozgathatóságát [16]. Általánosságban elmondható, hogy ha egy adott esetben nincs is szükség a fog sínezésére, a gyökéramputáción átesett fogak koronai részének restaurálására (legalább) teljes borítókoronát javasolnak [4, 11, 26]. Ennek oka a meggyengített struktúrában és a fog megerősítése iránti célban keresendő. Ugyanakkor mára számos vizsgálat bizonyítja, hogy az adhezíven ragasztott betétek (overlay) képesek ugyanúgy megerősíteni a fogat, mint egy teljes borítókorona [29], viszont jelentősen kevesebb foganyagáldozattal jár az elkészítésük. Mára a minimál invazív irányelvek alapján egyre több tudományos publikációban javasolják a korona indikációinak csökkentését [19, 24], helyette részleges koronák vagy extenzívebb betétek (overlay) alkalmazását ajánlják [20]. Vizsgálatunkban a gyökéramputált fogakat kompozit overlay-el láttuk el, követve a mai, modern restauratív irányelveket. Krug és mtsai. rávilágítottak arra, hogy az approximális kontaktpontok megléte jelentős szerepet játszhat a restaurátumok sikerességében és túlélésében [17]. Emiatt a restaurált mintákat a szomszédos fogakkal együtt, szoros approximális kontaktpontot formálva ágyaztuk be, így próbáltuk szimulálni a valós és egyben ideális klinikai állapotot.

Vizsgálatunkban a gyökéramputált és betéttel restaurált fogak töréssel szembeni ellenállását értékeltük. Ismert tény, hogy a gyökéramputált fogak elvesztésének leggyakoribb oka parodontális érintettség és csontpusztulás [25], majd gyakoriság szerint ezt követi a fogak törése, fraktúrája [22, 30]. Eredményeink szerint a gyökéramputált fogak statikus terheléssel szembeni törési ellenállásértékei arra utalnak, hogy az ép (fiziológiás mennyiségű) parodontális szövettel körülvett fogak jelentősen jobban ellenálltak az őket érő erőknek, mint a károsodott parodonciummal rendelkező fogak. Ennek az oka feltehetően abban keresendő, hogy a fogat érő erőhatás nagyobb felületen oszlik el ép parodoncium esetén. Nieri és mtsai. vizsgálata alapján a gyökéramputáció elvégzésekor a megtartandó gyökerek körül rendelkezésre álló csontos megtámasztás a legfontosabb prognosztikai tényező a parodontálisan érintett fog sikeressége és túlélése szempontjából [23]. Ez összhangban van Baima korábbi eredményeivel is [4]. Sajnos a szakirodalomban a mai napig nincs egyértelmú számadat a gyökéramputáción átesett fogak biztonságos megtámasztásához szükséges minimális csontmennyiség arányáról. Park és mtsai. azt találták, hogy ha a megtartott gyökerek teljes csontos megtámasztása több mint 50\%, az lényegesen jobb prognózist biztosít, mintha 50\%-nál kisebb csontmennyiség lenne [25]. A törési mintázat tekintetében azt tapasztaltuk, hogy az ép parodontális viszonyokat szimuláló, gyökéramputált esetekben a fog eltörésekor több volt a restaurálhatónak minősíthető törés, azaz, ahol a törésvonal lokalizációja lehetővé tette a fog újbóli restaurációját és funkcióban tartását. Sérült, ún. redukált parodoncium esetén a gyökerek megtámasztását szolgáló felület kisebb, így nagyobb feszülés jöhet létre a fogban, amely elvezetődés híán repedést, törést okoz. Jelen vizsgálatunkban a sérült parodonciummal körülvett fogak törése esetén minden esetben kedvezőtlen, nem restaurálható törés következett be.

Vizsgálatunkhoz azért használtunk felső moláris fogakat, mert egyes retrospektív vizsgálatok rávilágítottak arra, hogy agresszív vagy krónikus parodontitiszben szenvedő pácienseknél a felső molárisok sikertelensége és elvesztése gyakoribb (72\%), mint az alsóké (50\%) [9]. Ez megegyezik Walter és mtsai. állításával is [30]. Huynh-Ba és mtsai. szisztematikus áttekintő közleménye alapján a gyökéramputációt involváló parodontológiai mútéti beavatkozások sikeressége $62 \%$ és 100\% között változik 5-13 éves utánkövetés során [15]. A gyökéramputáció prognózisa jól dokumentált, ugyanakkor nagy különbségek mutatkoznak a különböző tanulmányok megállapításai szerint. Bizonyos eredmények alapján a gyökéramputált molárisok túlélése $90 \%$ feletti 10 év távlatában [8], viszont más tanulmányok szerint ez az érték csak $70 \%$ [6]. A vizsgálatokból és ajánlásokból leszűrve elmondható, hogy a gyökéramputáció sikeressége nagyban függ a választott technikától, emiatt rendkívül fontos a megfelelő eset kiválasztása $[10,16,25]$.

\section{Következtetés}

In vitro vizsgálatunk korlátait figyelembe véve, eredményeink alapján úgy tűnik, hogy a gyökéramputált és betéttel restaurált, de ép parodonciummal körülvett fogak ellenállóbbak a terheléssel szemben, mint az azonos módon restaurált, de furkáció-érintett parodontális defektussal körülvett fogak. Ugyanakkor további vizsgálatok szükségesek ezen eredmények statisztikai alátámasztására. Továbbá megállapítható, hogy a gyökerek csontos megtámasztottsága, azaz a parodoncium állapota a törés mintázatát, így a fog restaurálhatóságát is befolyásolja.

\section{Irodalom}

1. Amen C: Hemisection and root amputation. Periodontics 1966; 197.

2. American Academy of Periodontology: Glossary of Periodontal Terms. [4th ed.] Chicago, USA, American Academy of Periodontology, 2001; 45.

3. ApPleton IE: Restoration of root-resected teeth. J Prosthet Dent. 1980; 150-153.

4. BaImA RF: Considerations for furcation treatment. Part III: Restorative therapy. J Prosthet Dent. 1987; 145-147.

5. Basaraba N: Root amputation and tooth hemisection. Dent Clin North Am. 1969; 121-132.

6. Blomlöf L, Jansson L, Appelgren R, Ehnevid H, Lindskog S: Prog- 
nosis and mortality of root-resected molars. Int $\mathrm{J}$ Periodontics Restorative Dent. 1997; 190-201.

7. Cara RR, Fleming GJ, Palin WM, Walmsley AD, Burke FJ: Cuspal deflection and microleakage in premolar teeth restored with resin-based composites with and without an intermediary flowable layer. J Dent. 2007; 482-489.

8. Carnevale G, Pontoriero R, di Febo G: Long-term effects of rootresective therapy in furcation-involved molars. A 10-year longitudinal study. J Clin Periodontol. 1998; 209-214.

9. Dannewitz B, Krieger JK, Hüsing J, Eickholz P: Loss of molars in periodontally treated patients: a retrospective analysis five years or more after active periodontal treatment. $J$ Clin Periodontol. 2006; 53-61.

10. DăguCI C, DăguCI L, Bătăıosu $M$, Popescu MR, Bunget $A$, MărgăRIT $\mathrm{R}$, et al.: Changing the root morphology in a case of periodontal impairment at a maxillary molar used as a sustaining tooth. Rom $\checkmark$ Morphol Embryol. 2014; 957-960.

11. DeSanctis M, Murphy KG: The role of resective periodontal surgery in the treatment of furcation defects. Periodontol 2000. 2000; 154-168.

12. Ducar JP, Tsutsui F, Merin RL: Therapeutic choices in the molar region. J Calif Dent Assoc. 2002 May;30(5); 355-361. Review

13. Hamp SE, Nyman S, Lindie J: Periodontal treatment of multirooted teeth. Results after 5 years. J Clin Periodontol. 1975; 126-135.

14. Hermann DW, Gher ME Jr, Dunlap RM, Pelleu GB Jr: The potential attachment area of the maxillary first molar. J Periodontol. 1983; 431-434.

15. Huynh-Ba G, Kuonen P, Hofer D, Schmid J, Lang NP, Salvi Ge: The effect of periodontal therapy on the survival rate and incidence of complications of multirooted teeth with furcation involvement after an observation period of at least 5 years: a systematic review. J Clin Periodontol. 2009; 164-176.

16. KLAVAN B: Clinical observations following root amputation in maxillary molar teeth. J Periodontol. 1975; 1-5.

17. Krug KP, Otter Se, Knauber AW, Erdelt KJ, Nothdurft FP: Influence of proximal contacts and FRC posts on the fracture behavior of premolars with class II composite restorations: an invitro study. Dent Mater J. 2013; 952-958.

18. Loos B, Nylund K, Claffey N, Egelberg J: Clinical effects of root debridement in molar and non-molar teeth. A 2-year follow-up. J Clin Periodontol. 1989; 498-504.

19. Magne $P$, Carvalho AO, Bruzi G, Giannini M: Fatigue resistance of ultrathin CAD/CAM complete crowns with a simplified cementation process. J Prosthet Dent. 2015; 574-579.

20. Magne $P, K_{\text {NEZEVIC }}$ A: Simulated fatigue resistance of composite resin versus porcelain CAD/CAM overlay restorations on endodontically treated molars. Quintessence Int. 2009; 125-133.

21. MCFALL WT JR: Tooth loss in 100 treated patients with periodontal disease. A long-term study. J Periodontol. 1982; 539-549.

22. Needleman I: How long do multirooted teeth with furcaion involvement survive with treatment? Evid Based Dent. 2010; 38-39.

23. Nieri M, Muzzi L, Cattabriga M, Rotundo R, Cairo F, Pini Prato GP: The prognostic value of several periodontal factors measured as radiographic bone level variation: a 10-year retrospective mul-

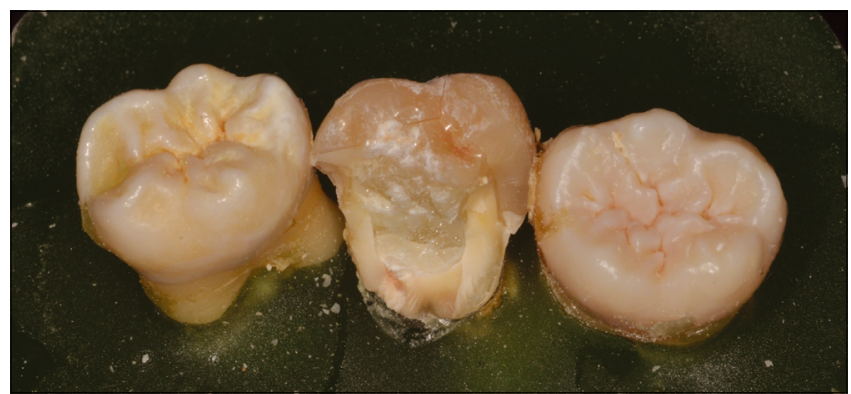

2. kép: Egy beágyazott minta, amin egy nem restaurálható törés látahtó.

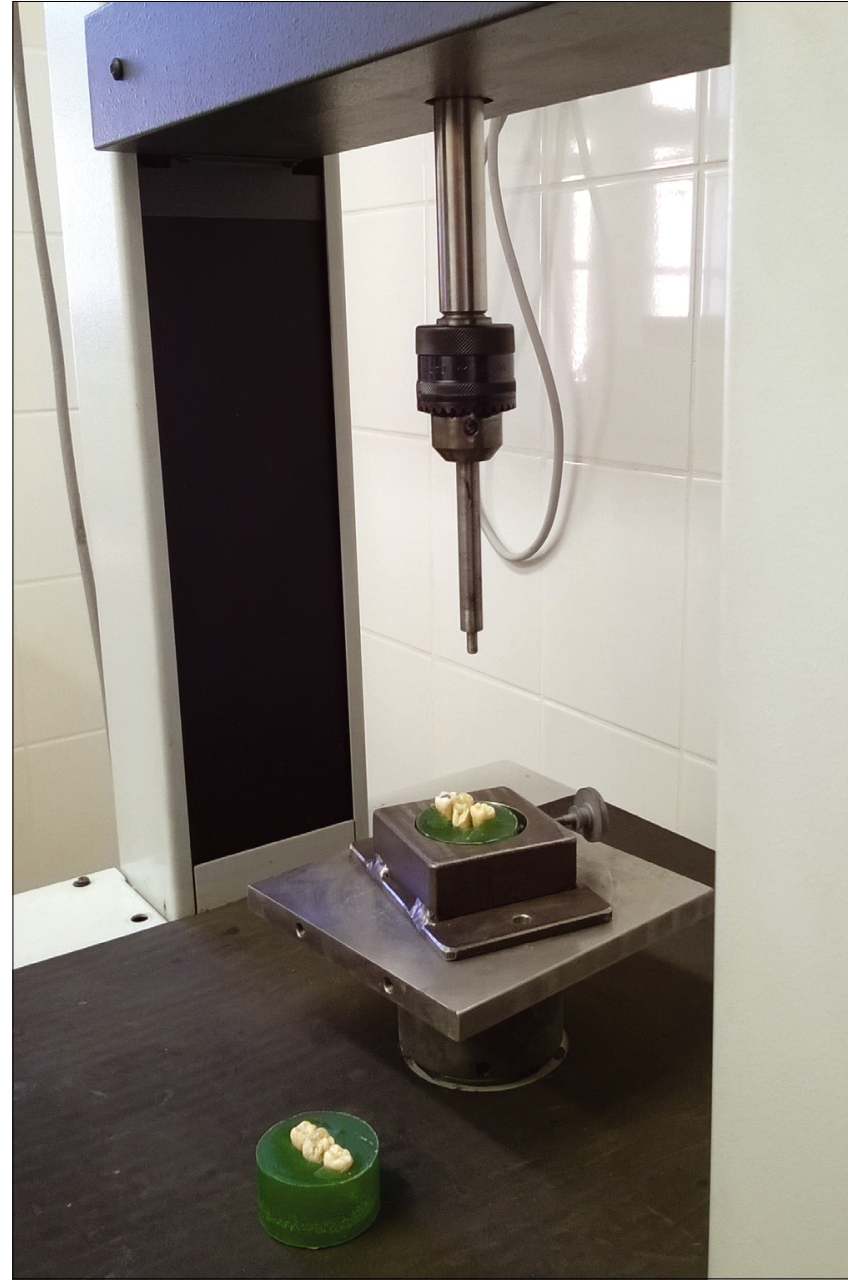

3. kép: A mérésre, mechanikai tesztelésre használt műszer

tilevel analysis of treated and maintained periodontal patients. J Periodontol. 2002; 1485-1493.

24. Opdam N, Frankenberger R, Magne P: From 'Direct Versus Indirect' Toward an Integrated Restorative Concept in the Posterior Dentition. Oper Dent. 2016; S27-S34.

25. PARK SY, SHIN SY, YANG SM, KYE SB: Factors influencing the outcome of root-resection therapy in molars: a 10-year retrospective study. J Periodontol. 2009; 32-40.

26. SCHMITT SM, BRown FH: Management of root-amputated maxillary molar teeth: periodontal and prosthetic considerations. J Prosthet Dent. 1989; 648-652.

27. Scotti N, Coero Borga Fa, Alovisi M, Rota R, Pasqualini D, BERUTTI $E$ : Is fracture resistance of endodontically treated mandibular molars restored with indirect onlay composite restorations influenced by fibre post insertion? J Dent. 2012; 814-820.

28. Solomon CS, Osman YI: Aesthetic restoration of the compromised root: a case report. SADJ. 2003; 370, 373-376, 381.

29. Yu W, Guo K, ZhANG B, Weng W: Fracture resistance of endodontically treated premolars restored with lithium disilicate CAD/CAM crowns or onlays and luted with two luting agents. Dent Mater J. 2014; 349-354.

30. Walter C, Weiger R, Zitzmann NU: Periodontal surgery in furcation-involved maxillary molars revisited-an introduction of guidelines for comprehensive treatment. Clin Oral Investig. 2011; 9-20.

31. Wu Y, Cathro P, Marino V. Fracture resistance and pattern of the upper premolars with obturated canals and restored endodontic occlusal access cavities. J Biomed Res. 2010 Nov; 24(6); 474-478. 


\title{
Szabó B, EÖrdegh G, Szabó PB, Fráter M
}

\section{In vitro fracture resistance of root amputated molar teeth restored with overlay} Pilot study

Background: The purpose of this study is to evaluate the effect of different amount of periodontal support around root amputated maxillary root canal treated molar teeth restored with overlay restorations.

Methods: Fourteen extracted and root canal treated maxillary molars were used. Standard sized MOD cavities were prepared and subsequently the teeth received core build-up and overlay restorations. The restored teeth underwent root amputation of the mesiobuccal roots. The specimens were divided into two groups depending on the amount of periodontal support around the remaining roots. The specimens were submitted to static fracture resistance test. Fracture thresholds and fracture patterns were measured and evaluated.

Results: The fracture resistance of root amputated teeth with sound periodontal support yielded higher fracture resistance $($ mean $=2655,53 \mathrm{~N}, \mathrm{SD}= \pm 1107,27 \mathrm{~N}, \mathrm{n}=7$ ) than the ones with damaged periodontal support $($ mean $=1624,12 \mathrm{~N}$, $\mathrm{SD}= \pm 535,03 \mathrm{~N}, \mathrm{n}=7$ ) Regarding the fracture pattern of latter group all the samples exhibited unfavourable fractures, whereas the ratio of favourable and unfavourable was approximately the same in the group with sound periodontal support.

Conclusions: Within the limitations of this study, the amount of periodontal support seems to show some correlation with the fracture resistance of root amputated and restored maxillary molars. It had a positive impact on the fracture pattern of these teeth as well. Thus the amount of periodontal support can be a key element regarding the success rate of root amputated maxillary molars and can influence also the decision making process of the operator.

Keywords: root amputation, furcation, fracture resistance, overlay, root canal treated tooth

\section{Beszámoló a Nemzetközi Gyermekfogászati Társaság 10. európai kongresszusáról}

\author{
2017. április 20-22., Torino, Olaszország
}

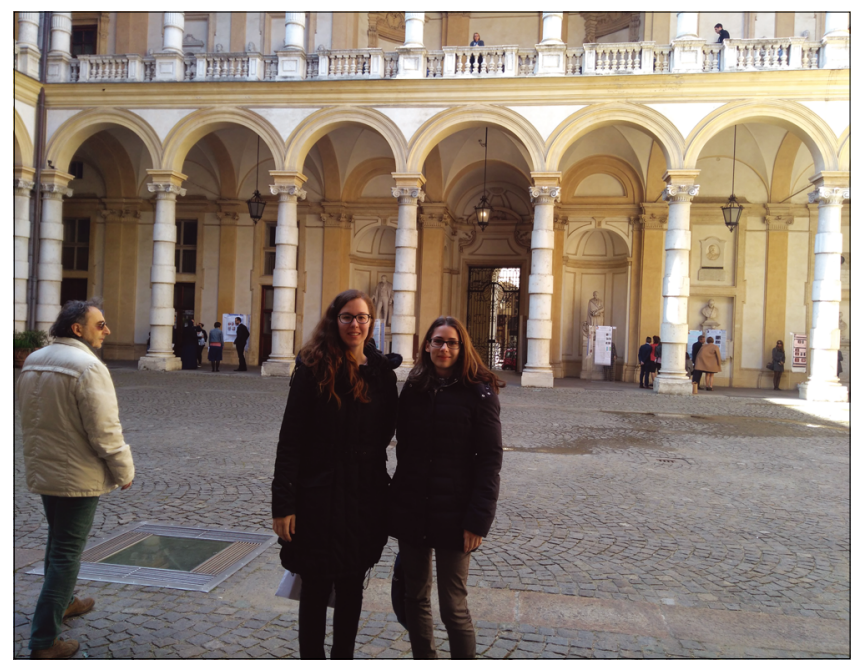

A Nemzetközi Gyermekfogászati Társaság nagy érdeklődés mellett Torinóban rendezte meg 10. európai kongresszusát. A találkozó fő célkitúzése új szakmai irányelvek kidolgozása volt a gyermekfogászatban az érzéstelenítők használata terén. A rendezvény három napja alatt színvonalas előadásokat hallgathattunk gyermekek szájsebészeti és fogszabályozási ellátásáról, illetve sérült fiatalok általános érzéstelenítésben történő kezelésével kapcsolatban. A konferencia workshopjain a téma szakértöi új irányelveket fogadtak el a helyi érzéstelenítök használatáról, melyek nemsokára olvashatók lesznek a társaság honlapján (www.eapd.eu).

Több előadó beszámolt tudományos kutatásainak módszereiről, lépésenként ismertetve egy tudományos publikáció létrejöttét, hangsúlyozva az evidence based információk fontosságát. A rendezvénynek az északolasz város ódon egyetemi épületei adtak otthont, és az ezer éves falak között mutatták be újdonságaikat a fogászati cégek, a rendezvényt kísérő kiállítás során.

A budapesti Semmelweis Egyetem Gyermekfogászati és Fogszabályozási Klinikáját ketten képviselték poszterprezentációkkal. Dr. Mlinkó Éva a moláris-incizális hypomineralizáció $(\mathrm{MIH})$ szindróma fő etiológiai faktorairól és prevalenciájáról készült budapesti felmérés eredményeit ismertette. Dr. Nagy Dóra Zsófia egy négyéves kisfiú trauma miatt létrejött nagyfokú tejfrontfog-hiányának kezelési lehetőségét mutatta be.

A szakmai programokon kívül a város és környéke színes programokkal várta az ide érkezőket, az esti vacsorákon, összejöveteleken pedig a konferencia résztvevői beszélgethettek, tapasztalatokat cserélhettek egymással. 